\title{
Development of chitosan microparticles for controlled release of metoprolol tartarate
}

\section{Metoprolol tartaratın kontrollü salımı için kitozan mikropartiküllerinin geliştirilmesi}

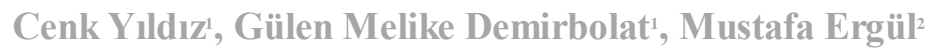

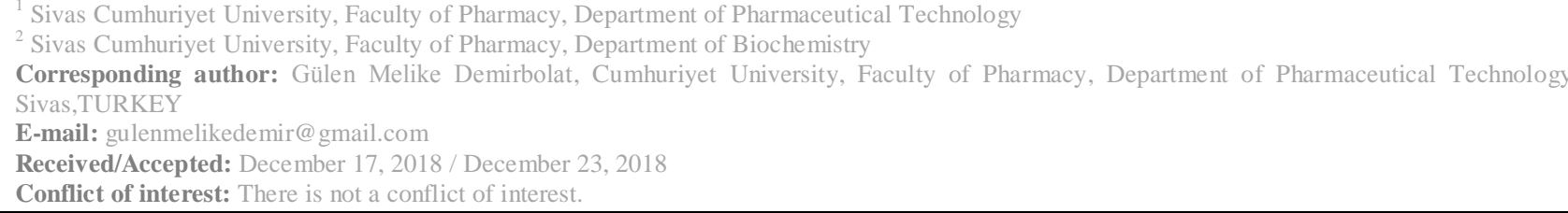

\section{SUMMARY}

Hypertension, defined as high blood pressure, is a common medical condition leading to cardiovascular disability and premature deaths. Blood pressure control in an efficient way are assumed to the main targets to prevent hypertension. Since conventional dosage forms (e.g. immediate release tablets, capsules, etc.) show some limitation, greater attention is being paid on designing the modified drug release systems. Modified release is defined as drug releasing from dosage form some time after the administration or in prolonged period of time. In this study, we aimed to design metoprolol tartarate loaded chitosan microparticles to obtained modified drug release. Chitosan microparticles produced via ionic gelation with tripolyphosphate as a crosslinking agent. Prepared formulations were characterized and metoprolol tartarate was loaded into the optimal blank microspheres. The entrapment efficiency, drug loading, cell viability assay and in vitro drug release were investigated. Optimum formulation was spherical and had $81 \%$ of yield and $75.373 \pm 7.384 \mu \mathrm{m}$ particle size. $16 \mathrm{mg}$ of metoprolol tartarate could be loaded into microparticles and drug release could be maintained for 48 hours.

Keywords: chitosan, metoprolol tartarate, controlled release, microparticles

\section{ÖZET}

Yüksek kan basıncı olarak tanımlanan hipertansiyon kardiyovasküler yetersizliklere ve erken ölümlere neden olan yaygın medical bir durumdur. Kan basıncının etkili bir şekilde kontrol altına alınması hipertansiyonun önlenmesinde ana hedef olarak kabul edilmektedir. Konvansiyonel dozaj formlarının (hemen salım yapan tabletler, kapsüller gibi) bazı kısıtlamalara sahip olmaları nedeniyle modifiye ilaç salım sistemlerinin tasarımı büyük ilgi uyandırmıștır. Modifiye salım; ilacın verilișinden belli bir süre sonrasında veya uzatılmıș bir zaman diliminde dozaj formundan ilacın çıkışı olarak tanımlanmaktadır. Bu çalışmada, modifiye salım elde etmek için metoprolol tartarat yüklü kitozan mikropartiküllerinin üretilmesi amaçlanmıştır. Kitozan mikropartikülleri; çapraz bağlı ajan olarak kullanılan tripolifosfat ile iyonik jelasyon yöntemine göre üretilmiştir. Hazırlanan formülasyonlar karakterize edilmiş ve etkin madde içermeyen optimum mikropartiküllere metoprolol tartarat yüklenmiştir. İlaç yükleme kapasitesi, yükleme etkinliği, hücre canlılığı ve in vitro ilaç salımı incelenmiştir. En iyi formülasyon küresel yapılı \%81 verim ile $75.373 \pm 7.384 \mu \mathrm{m}$ partikül büyüklüğünde elde edilmiştir. Micropartiküllere $16 \mathrm{mg}$ metoprolol tartarat yüklenebilmiş ve ilaç salımı 48 saat boyunca sürdürülmüştür.

Anahtar sözcükler: kitosan, metoprolol tartarat, kontrollü salım, mikropartiküller 


\section{INTRODUCTION}

Hypertension, defined as high blood pressure, is a common medical condition leading to cardiovascular disability and premature deaths ${ }^{1,2}$. It is because the higher pressure, the harder is to contract the heart ${ }^{3}$. To controlling the blood pressure, there are five major pharmacological classes of antihypertensive drugs; beta blockers, diuretics, angiotensin-converting enzyme inhibitors, angiotensin II receptor antagonists, and calcium channel blockers ${ }^{4}$. Beta-blockers have been used as one of the first-line therapies for hypertension since the late 1960s. Small reductions in blood pressure can significantly reduce associated morbidity and mortality risks so that the rationale for treating hypertension gain great interest. Blood pressure control in an efficient way or reducing the dosages of drugs are assumed to the main targets ${ }^{5,6}$.

Conventional dosage forms (e.g. immediate release tablets, capsules, etc.) show some limitation such as i. poor patient compliance due to the necessity of frequently administration that leads to increased chances of missing the dose of a drug and non-specific biodistribution, ii. the unavoidable fluctuation of drug concentration in blood, in particular, for the multiple-dose regimen that may cause under or over medication, means that poor oral bioavailability, iii. impracticability to attain steady-state condition with a typical

\section{MATERIAL AND METHODS}

\section{Materials}

Chitosan from shrimp shells (75\% deacetylated, at around 200cP viscosity), tripolyphosphate and metoprolol tartarate were purchased from Sigma Aldrich, Germany. Glacial acetic acid was obtained from Fischer Scientific.

\section{Methods}

\section{Preparation of Blank Chitosan Microparticles}

Ionotropic gelation method was carried out as previously described by Mothilal et al. except that chitosan was crosslinked with glutaraldehyde ${ }^{11}$. peak-valley plasma concentration versus time profile. Greater attention is being paid on designing the modified drug release systems to overcome these disadvantages ${ }^{7,8}$. Modified release is defined as drug releasing from dosage form some time after the administration or in prolonged period of time while immediate release is defined as drug releasing from dosage form immediately after administration ${ }^{9}$. Since the early 1980s, numbers of pharmaceutical products using novel drug delivery systems are increasingly prescribed day by day for the treatment of systemic hypertension by physicians ${ }^{10}$.

In this study, we aimed to design metoprolol tartarate loaded chitosan microparticles to obtained modified drug release. Chitosan microparticles produced via ionic gelation with tripolyphosphate as a crosslinking agent. On the prepared formulations, the percentage of yield, particle size and morphology, swelling behavior were evaluated as formulation properties. After metoprolol tartarate (MT) was loaded into the optimal blank microspheres that was selected according to findings of formulation characterization, the entrapment efficiency, drug loading and cell viability assay were also investigated. On the other hand, we filled MT loaded microparticles into the capsules. In vitro drug release for MT loaded microparticles in capsules was performed besides these abovementioned experiments.

Weigh amount chitosan (without the need to milling) was dissolved in $1 \%(\mathrm{v} / \mathrm{v})$ aqueous glacial acetic acid, then it was left under stirring at $1000 \mathrm{rpm}$ at room temperature for 24 hours. Chitosan solution was added dropwise using a 21gauge syringe to the tripolyphosphate (TPP) solution in water with continues stirring at 500 rpm. Stirring was continued for $5 \mathrm{~min}$ after the complete addition of chitosan solution to TPP. We prepared twenty-seven different formulations to observe the variation of formulation properties depends on the polymer:crosslinking agent ratio given in Table 1. The obtained microparticles was filtered using filter paper, before they were dried at $40^{\circ} \mathrm{C}$ for $24 \mathrm{~h}^{12-14}$. 
Table 1. The composition of blank microparticles

\begin{tabular}{|c|c|c|c|c|c|c|c|c|c|c|}
\hline Form. & The Percentage & \multicolumn{9}{|c|}{ The Percentage of TPP } \\
\hline F1 & \multirow{9}{*}{1} & 0.025 & - & - & - & - & - & - & - & - \\
\hline F2 & & - & 0.05 & - & - & - & - & - & - & - \\
\hline F3 & & - & - & 0.125 & - & - & - & - & - & - \\
\hline F4 & & - & - & - & 0.25 & - & - & - & - & - \\
\hline F5 & & - & - & - & - & 0.375 & - & - & - & - \\
\hline F6 & & - & - & - & - & - & 0.50 & - & - & - \\
\hline F7 & & - & - & - & - & - & - & 0.1 & - & - \\
\hline F8 & & - & - & - & - & - & - & - & 0.2 & - \\
\hline F9 & & - & - & - & - & - & - & - & - & 0.3 \\
\hline F10 & \multirow{9}{*}{1.5} & 0.025 & - & - & - & - & - & - & - & - \\
\hline F11 & & - & 0.05 & - & - & - & - & - & - & - \\
\hline F12 & & - & - & 0.125 & - & - & - & - & - & - \\
\hline F13 & & - & - & - & 0.25 & - & - & - & - & - \\
\hline F14 & & - & - & - & - & 0.375 & - & - & - & - \\
\hline F15 & & - & - & - & - & - & 0.50 & - & - & - \\
\hline F16 & & - & - & - & - & - & - & 0.1 & - & - \\
\hline F17 & & - & - & - & - & - & - & - & 0.2 & - \\
\hline F18 & & - & - & - & - & - & - & - & - & 0.3 \\
\hline F19 & \multirow{9}{*}{2} & 0.025 & - & - & - & - & - & - & - & - \\
\hline F20 & & - & 0.05 & - & - & - & - & - & - & - \\
\hline F21 & & - & - & 0.125 & - & - & - & - & - & - \\
\hline F22 & & - & - & - & 0.25 & - & - & - & - & - \\
\hline F23 & & - & - & - & - & 0.375 & - & - & - & - \\
\hline F24 & & - & - & - & - & - & 0.50 & - & - & - \\
\hline F25 & & - & - & - & - & - & - & 0.1 & - & - \\
\hline F26 & & - & - & - & - & - & - & - & 0.2 & - \\
\hline F27 & & - & - & - & - & - & - & - & - & 0.3 \\
\hline
\end{tabular}


Particle Size and Morphology

Samples of the microparticles were analyzed for particle size and morphology by optical microscopy method using Noval N-120 with a calibrated micrometer for randomly selected samples of all the formulations ${ }^{11}$.

\section{Swelling Behaviour}

The swelling degree of microspheres (SW) was determined by introducing weight amount of chitosan microspheres in a glass vial containing $20 \mathrm{~mL}$ of $0.1 \mathrm{~N} \mathrm{HCl} \mathrm{pH} 1.2$ (to simulate gastric fluid) or phosphate buffer saline (PBS) pH 6.8 (to simulate intestinal fluid). The swelled microspheres were removed from the solution at predetermined intervals (1,2, 4 and 24 hours later), dried on a filter paper and weighed. The swelling degree was computed by the following equation:
SW=Wt-W0W0

$\mathrm{W}_{\mathrm{t}}$ defines the mass of the swelled microspheres (weighted at different time intervals) while $\mathrm{W}_{0}$ defines the initial mass of dried microspheres ${ }^{15}$.

\section{Preparation of Metoprolol Tartarate Loaded Chitosan Microparticles}

Drug loaded microspheres were obtained with the same method, after MT dissolved in chitosan solution or tripolyphosphate solution. As microparticles obtained by loaded MT into the tripolyphosphate solution were not spherical or separated with each other (data not shown), MT was added into the chitosan solution. All other steps were the same as previously explained. MT loaded formulations were given in Table 2 .

Table 2. The composition of drug loaded microparticles

\begin{tabular}{|c|l|c|c|c|c|c|}
\hline & & MC1 & MC2 & MC3 & MC4 & MC5 \\
\hline $\begin{array}{c}\text { Solution } \\
\text { A }\end{array}$ & Chitosan (\%) & 1.5 & 1.5 & 1.5 & 1.5 & 1.5 \\
\cline { 2 - 7 } & Metoprolol tartarate (mg) & 50 & 75 & 100 & $100 *$ & 200 \\
\hline $\begin{array}{c}\text { Solution } \\
\text { B }\end{array}$ & TPP (\%) & 0.375 & 0.375 & 0.375 & 0.375 & 0.375 \\
\hline
\end{tabular}

*: The MC4 coded formulation was incubated for 3 days.

\section{Determination of drug loading and encapsulation efficiency}

Drug loading and encapsulation efficiency of prepared MT loaded chitosan microparticles was determined by indirect method. Briefly, microparticles suspensions were filtered with filter paper and the supernatants were measured for free metoprolol tartarate by using UV spectrophotometer (UV-Pharmaspec6100, MAPADA Instruments) at $274 \mathrm{~nm}$. Quantifications were done by using the calibration curve, and drug loading and encapsulation efficiency were calculated according to following formula ${ }^{13,16}$ :

Drug Loading \%=total amount of MT-free MTmicroparticles weight x 100

Entrapment Efficiency \%=total amount of MTfree MTtotal amount of MT x 100

\section{Cell culture conditions and reagents}

The mouse fibroblast cell line L929 was acquired from American Type Culture Collection (Manassas, VA, USA) and was cultured in Dulbecco's modified Eagle's medium (DMEM) (Gibco Thermo Fisher Scientific) supplemented with $10 \%(\mathrm{v} / \mathrm{v})$ heat-inactivated FBS and $1 \%$ penicillin/streptomycin (Gibco Thermo Fisher Scientific). The cells were cultured in a $25 \mathrm{~cm}^{2}$ cell culture flask and incubated at $37{ }^{\circ} \mathrm{C}$ in a $5 \%$ $\mathrm{CO}_{2}$ humidified atmosphere of until they reached approximately an 80-90\% confluence.

\section{Cell viability assay}

Cell viability was assessed using the XTT (2,3bis-(2-methoxy-4-nitro-5-sulfophenyl)-2Htetrazolium-5-carboxanilide) colorimetric assay 
(Roche Diagnostic, Germany) against the L929 cells. Dried MT loaded chitosan microparticles were weighted, dispersed in $1 \mathrm{~mL}$ water and crashed using a homogenizer. MT were dissolved and microparticles were diluted in DMEM prior to treatment. The L929 cells were seeded in 96-well plates at a density of $1 \times 10^{4}$ cells per well in 100 $\mu \mathrm{L}$ DMEM and the cells were treated with both MT alone and chitosan microparticles at various concentrations and incubated for $24 \mathrm{~h}$. At the end of the incubation period, for determination of living cells, $50 \mu \mathrm{L}$ XTT labeling mixture were added to each well and then the plates were incubated at $37^{\circ} \mathrm{C}$ for another $4 \mathrm{~h}$. After mixing, the absorbance of XTT-formazan was measured using a microplate (ELISA) reader at $450 \mathrm{~nm}$ against the control. All experiments were performed in three independent experiments and the cell viability was expressed in \% related to control (100\% of viability).

\section{Statistical Analyses}

Statistical analysis was carried out using IBM SPSS Statistic 25 version. All data are expressed as mean \pm SEM. Groups were compared statistically using general linear models of analysis of variance (ANOVA) followed by Tukey test and t-test when appropriate. Also, Kruskal-Wallis and Mann-Whitney U tests have been used when the parametric test assumptions have been violated. $\mathrm{P}<0.05$ was considered statistically significant.

\section{Evaluation of Drug Release Studies on Capsules}

In vitro release studies were performed using the USP Apparatus 2 (Paddle Apparatus). $500 \mathrm{~mL}$ of $0.1 \mathrm{~N} \mathrm{HCl}$ at $37^{\circ} \mathrm{C}$ as medium were placed in vessels and stirred at $50 \mathrm{rpm}$ for 2 hours. After 2 hours, $400 \mathrm{~mL}$ of $0.27 \mathrm{M} \mathrm{Na}_{2} \mathrm{HPO}_{4}$ were added to vessels to obtain $\mathrm{pH} 6.8$ in order to simulate intestinal medium. At predetermined times $(5,10$, 15, 30, minutes and 1, 2, 4, 6, 24 and 48 hours), 2 $\mathrm{mL}$ samples were withdrawn from the release medium and replaced with equal volume of fresh dissolution medium. Samples were assayed for drug released by measuring the absorbance at 228 $\mathrm{nm}$ and $274 \mathrm{~nm}$ for ASA and MT, respectively.

\section{RESULTS}

\section{Characterization of Blank Chitosan Microparticles}

The formation of chitosan microparticles through ionotropic gelation with cross-linking agents (TPP) were maintained. Increasing amount of chitosan $(1 \%, 1.5 \%$ and $2 \%)$ was used in formulations. TPP was diversified from 0.025 to $0.3 \%$ for each chitosan amount. The percentage of yield was calculated after dried microparticles were weighted and proportioned to total amount of added powder into the formulations. Besides the percentage of yield, particle sizes were also shown in Table 3. 
Table 3. The results of characterization studies

\begin{tabular}{|c|c|c|c|}
\hline Form. Code & Dried weight (g) & Yield \% & Particle Size \pm SD $(\mu \mathrm{m})$ \\
\hline F1 & $*$ & $*$ & $*$ \\
\hline F2 & $*$ & $*$ & $*$ \\
\hline F3 & $*$ & $*$ & $*$ \\
\hline F4 & 0.224 & 74.1 & $106.319 \pm 14.591$ \\
\hline F5 & 0.244 & 69.0 & $87.523 \pm 14.580$ \\
\hline F6 & 0.226 & 56.5 & $55.107 \pm 7.830$ \\
\hline F7 & 0.268 & 44.6 & $52.085 \pm 6.464$ \\
\hline F8 & 0.306 & 30.6 & $53.85 \pm 5.273$ \\
\hline F9 & 0.362 & 25.8 & $68.839 \pm 10.088$ \\
\hline F10 & $*$ & $*$ & $*$ \\
\hline F11 & $*$ & $*$ & $*$ \\
\hline F12 & $*$ & $*$ & $*$ \\
\hline F13 & 0.307 & 76.5 & $103.747 \pm 14.088$ \\
\hline F14 & 0.368 & 81.4 & $75.373 \pm 7.384$ \\
\hline F15 & 0.386 & 76.8 & $74.946 \pm 8.764$ \\
\hline F16 & 0.422 & 59.8 & $67.455 \pm 7.545$ \\
\hline F17 & 0.456 & 41.3 & $82.873 \pm 5.976$ \\
\hline F18 & 0.471 & 31.3 & $85.386 \pm 5.030$ \\
\hline F19 & $*$ & $*$ & $*$ \\
\hline F20 & $*$ & $*$ & $*$ \\
\hline F21 & $*$ & $*$ & $*$ \\
\hline F22 & 0.376 & 73.7 & $99,036 \pm 21,992$ \\
\hline F23 & 0.490 & 88.9 & $95,908 \pm 15,902$ \\
\hline F24 & 0.407 & 67.8 & $71,076 \pm 7,186$ \\
\hline F25 & 0.456 & 56.9 & $63,622 \pm 4,568$ \\
\hline F26 & 0.575 & 47.8 & $66,442 \pm 6,444$ \\
\hline F27 & 0.664 & 41.5 & $65,989 \pm 3,142$ \\
\hline
\end{tabular}

It was shown that the yield of microparticles decreased with increasing the amount of TPP. Increasing of TPP amount, particle sizes showed reduction up to at $0.1 \%$ of TPP and increment afterwards. Other than particle size measurement, morphological structure of microparticles were evaluated. The morphological images of formulations were also shown in Figure 3. 


\begin{tabular}{|c|c|c|c|c|c|c|c|c|}
\hline F1 & $\mathrm{F} 2$ & F3 & F4 & F5 & F6 & F7 & F8 & F9 \\
\hline$*$ & $*$ & * & & & & & & \\
\hline F10 & F11 & F12 & F13 & F14 & F15 & F16 & F17 & F18 \\
\hline$*$ & $*$ & $*$ & & & & & & \\
\hline F19 & $\mathrm{F} 20$ & $\mathrm{~F} 21$ & F22 & F23 & F24 & F25 & F26 & F27 \\
\hline$*$ & $*$ & * & & & & & & \\
\hline
\end{tabular}

Figure 1. The morphological images (*: not obtained microparticles)

All microparticles can be considered spherical but some of them was unruffled and smooth. The swelling behaviors of microspheres were investigated in both $0.1 \mathrm{~N} \mathrm{HCl} \mathrm{pH} 1.2$ and phosphate buffer saline $\mathrm{pH} 6.8$ to predict their behavior in stomach and small intestine. While initial weight referred to amount of dried microparticles, wet microparticles were also weighed at 1,2, 4 and 24 hours later.all the results were given in Table 4 . 
Table 4. Swelling behavior in $0.1 \mathrm{~N} \mathrm{HCl} \mathrm{pH} 1.2$ and PBS pH 6.8

\begin{tabular}{|c|c|c|c|c|c|c|c|}
\hline $\begin{array}{l}\text { Form. } \\
\text { Code }\end{array}$ & Medium & $\begin{array}{l}\text { Initial weight } \\
\text { (g) }\end{array}$ & $\begin{array}{c}1 \text { hour } \\
\text { (g) }\end{array}$ & $\begin{array}{c}2 \text { hour } \\
\text { (g) }\end{array}$ & $\begin{array}{l}4 \text { hour } \\
\text { (g) }\end{array}$ & $\begin{array}{c}24 \text { hour } \\
\text { (g) }\end{array}$ & $\begin{array}{c}\text { Increase in } \\
\text { weight }\end{array}$ \\
\hline \multirow[t]{2}{*}{ F4 } & $\mathrm{HCl}$ & 0,100 & 2,610 & 3,311 & 3,495 & 3,876 & 37,719 \\
\hline & PBS & 0,053 & 0,097 & 0,085 & 0,107 & 0,095 & 0,796 \\
\hline \multirow[t]{2}{*}{ F5 } & $\mathrm{HCl}$ & 0,100 & 1,047 & 1,428 & 1,772 & 2,032 & 19,241 \\
\hline & PBS & 0,056 & 0,107 & 0,103 & 0,106 & 0,119 & 1,138 \\
\hline \multirow[t]{2}{*}{ F6 } & $\mathrm{HCl}$ & 0,101 & 0,583 & 0,705 & 0,950 & 1,344 & 12,322 \\
\hline & PBS & 0,052 & 0,092 & 0,095 & 0,093 & 0,105 & 1,041 \\
\hline \multirow{2}{*}{ F7 } & $\mathrm{HCl}$ & 0,100 & 0,274 & 0,422 & 0,625 & 0,991 & 8,906 \\
\hline & PBS & 0,052 & 0,093 & 0,092 & 0,09 & 0,102 & 0,946 \\
\hline \multirow[t]{2}{*}{ F8 } & $\mathrm{HCl}$ & 0,100 & 0,229 & 0,393 & 0,629 & 1,099 & 9,950 \\
\hline & $\mathrm{PBS}$ & 0,054 & 0,087 & 0,090 & 0,092 & 0,100 & 0,850 \\
\hline \multirow[t]{2}{*}{ F9 } & $\mathrm{HCl}$ & 0,100 & 0,297 & 0,719 & 1,904 & 3,479 & 33,654 \\
\hline & PBS & 0,051 & 0,080 & 0,082 & 0,085 & 0,101 & 0,980 \\
\hline \multirow[t]{2}{*}{ F13 } & $\mathrm{HCl}$ & 0,101 & 1,995 & 2,564 & 2,891 & 2,884 & 27,670 \\
\hline & PBS & 0,055 & 0,124 & 0,137 & 0,143 & 0,157 & 1,853 \\
\hline \multirow[t]{2}{*}{ F14 } & $\mathrm{HCl}$ & 0,102 & 1,164 & 2,026 & 3,015 & 3,485 & 33,098 \\
\hline & PBS & 0,053 & 0,091 & 0,095 & 0,105 & 0,130 & 1,448 \\
\hline \multirow[t]{2}{*}{ F15 } & $\mathrm{HCl}$ & 0,101 & 0,582 & 0,799 & 1,009 & 1,309 & 11,999 \\
\hline & PBS & 0,055 & 0,092 & 0,093 & 0,099 & 0,115 & 1,098 \\
\hline \multirow[t]{2}{*}{ F16 } & $\mathrm{HCl}$ & 0,101 & 0,318 & 0,462 & 0,634 & 0,925 & 8,131 \\
\hline & PBS & 0,054 & 0,068 & 0,080 & 0,088 & 0,114 & 1,090 \\
\hline \multirow[t]{2}{*}{ F17 } & $\mathrm{HCl}$ & 0,103 & 0,363 & 0,599 & 1,079 & 1,896 & 17,376 \\
\hline & PBS & 0,051 & 0,070 & 0,076 & 0,082 & 0,122 & 1,395 \\
\hline \multirow[t]{2}{*}{ F18 } & $\mathrm{HCl}$ & 0,103 & 0,337 & 0,462 & 0,857 & 1,992 & 18,279 \\
\hline & PBS & 0,051 & 0,081 & 0,088 & 0,089 & 0,093 & 0,827 \\
\hline \multirow[t]{2}{*}{ F22 } & $\mathrm{HCl}$ & 0,101 & 1,498 & 2,081 & 2,596 & 3,236 & 31,103 \\
\hline & PBS & 0,054 & 0,110 & 0,118 & 0,128 & 0,152 & 1,806 \\
\hline \multirow[t]{2}{*}{ F23 } & $\mathrm{HCl}$ & 0,101 & 2,147 & 2,971 & 3,644 & 4,248 & 41,271 \\
\hline & PBS & 0,053 & 0,117 & 0,123 & 0,134 & 0,167 & 2,118 \\
\hline \multirow[t]{2}{*}{ F24 } & $\mathrm{HCl}$ & 0,101 & 0,502 & 0,702 & 0,845 & 1,069 & 9,574 \\
\hline & PBS & 0,054 & 0,102 & 0,103 & 0,108 & 0,126 & 1,339 \\
\hline \multirow[t]{2}{*}{ F25 } & $\mathrm{HCl}$ & 0,101 & 0,299 & 0,797 & 0,656 & 0,883 & 7,787 \\
\hline & PBS & 0,052 & 0,090 & 0,091 & 0,095 & 0,110 & 1,088 \\
\hline \multirow[t]{2}{*}{ F26 } & $\mathrm{HCl}$ & 0,101 & 0,242 & 0,395 & 0,634 & 1,003 & 8,974 \\
\hline & PBS & 0,056 & 0,091 & 0,092 & 0,097 & 0,113 & 1,004 \\
\hline \multirow[t]{2}{*}{ F27 } & $\mathrm{HCl}$ & 0,101 & 0,225 & 0,326 & 0,428 & 0,695 & 5,881 \\
\hline & PBS & 0,052 & 0,087 & 0,087 & 0,087 & 0,098 & 0,885 \\
\hline
\end{tabular}

All formulations highly swelled up to $41,271 \%$ in acidic medium while they remained below $2 \%$ in basic medium. We also captured images of F14 coded formulation at $0.1 \mathrm{~N} \mathrm{HCl} \mathrm{pH} 1.2$ and phosphate buffer saline $\mathrm{pH}$ 6.8. The images were shown in Figure 3. 


\begin{tabular}{|c|c|c|c|c|c|c|c|}
\hline Medium & Initial & $15 \mathrm{~min}$. & $30 \mathrm{~min}$. & 1 hour & 2 hours & 4 hours & 24 hours \\
\hline $\begin{array}{c}0.1 \mathrm{~N} \\
\mathrm{HCl} \\
\mathrm{pH} 1.2\end{array}$ & 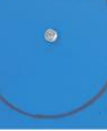 & 0 & 0 & 8 & (c) & 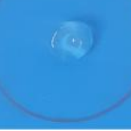 & $x$ \\
\hline $\begin{array}{c}\text { PBS } \\
\mathrm{pH} 6.8\end{array}$ & - & $\theta$ & - & 0 & 0 & D & ச \\
\hline
\end{tabular}

Figure 2. Swelling behavior of F14 coded formulation in gastric and small intestinal medium

\section{Characterization of MT Loaded Chitosan} Microparticles

After optimal formulation was determined in terms of the percentage of yield, particle size, morphology and swelling behavior, five more formulations were studied to load metoprolol tartarate into microparticles. The effect of drug amount and incubation strength on entrapment efficiency were also investigated.

Table 5. Characterization of metoprolol tartarate loaded microparticles

\begin{tabular}{|l|c|c|c|c|c|}
\hline Properties & MC1 & MC2 & MC3 & MC4 & MC5 \\
\hline Dried weight & 0.37 & 0.40 & 0.42 & 0.37 & 0.44 \\
\hline Yield (\%) & 74.5 & 75.1 & 75.1 & 66.3 & 67.3 \\
\hline Entrapment Efficiency (\%) & 1.85 & 4.25 & 16.60 & 14.65 & 48.10 \\
\hline Drug Loading (\%) & 0.19 & 0.60 & 3.07 & 2.66 & 14.76 \\
\hline
\end{tabular}

It was clear that the more drug used in formulations, the more entrapment efficiency obtained. MC1 and MC2 notably fell behind the others in terms of entrapment efficiency. MC3 and MC4 had close amount of MT, although MC4 was incubated for 3 days.

The in vitro cytotoxicity of MC3 coded formulation and the equal amount of metoprolol tartarate were evaluated on L929 cell line with the XTT assay and the results are given in Figure 4. According to the experimental results, none of these compounds exhibited any cytotoxicity on the L929 cell line at the four different concentrations. The concentration of $\mathrm{MT}$ on $\mathrm{CH}-$ MP $100 \%$ was equal to the concentration of drug release studies and MT in Figure 4.

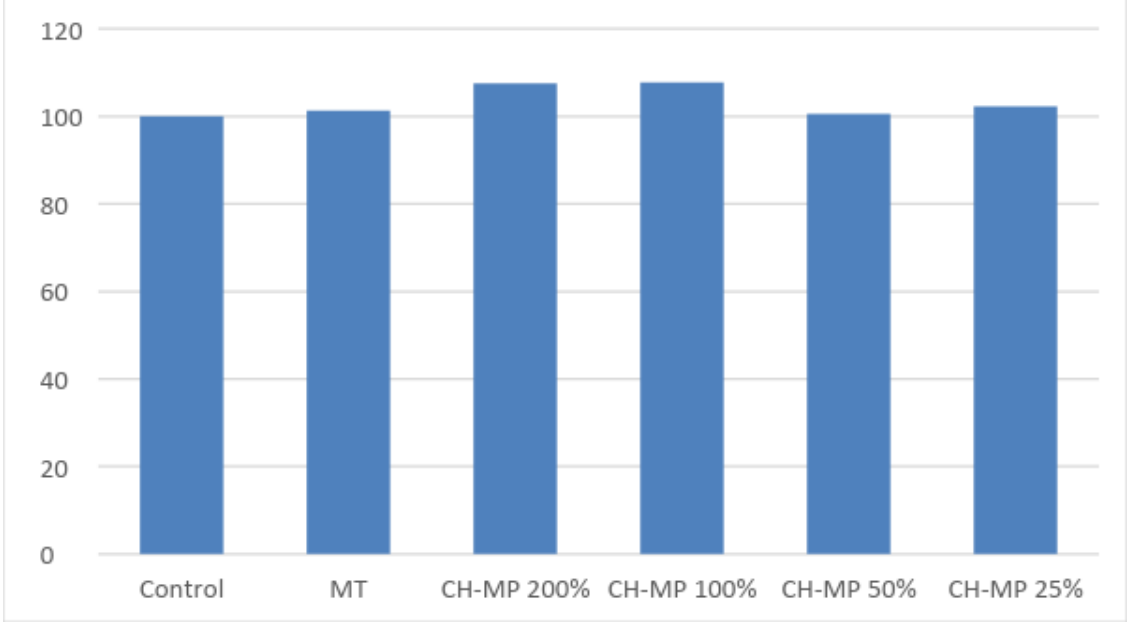


Figure 3. Cytotoxicity assay for MT loaded microparticles (MP)

Evaluation of Drug Release Studies on Capsules

Produced microparticles included $16.6 \mathrm{mg}$ metoprolol tartarate were filled in capsules. Dissolution test was fulfilled according to USP
Apparatus II, mentioned in Methods, "Evaluation of Drug Release Studies on Capsules". The percentage of drugs versus time was drawn in a graph, seen in Figure 5.

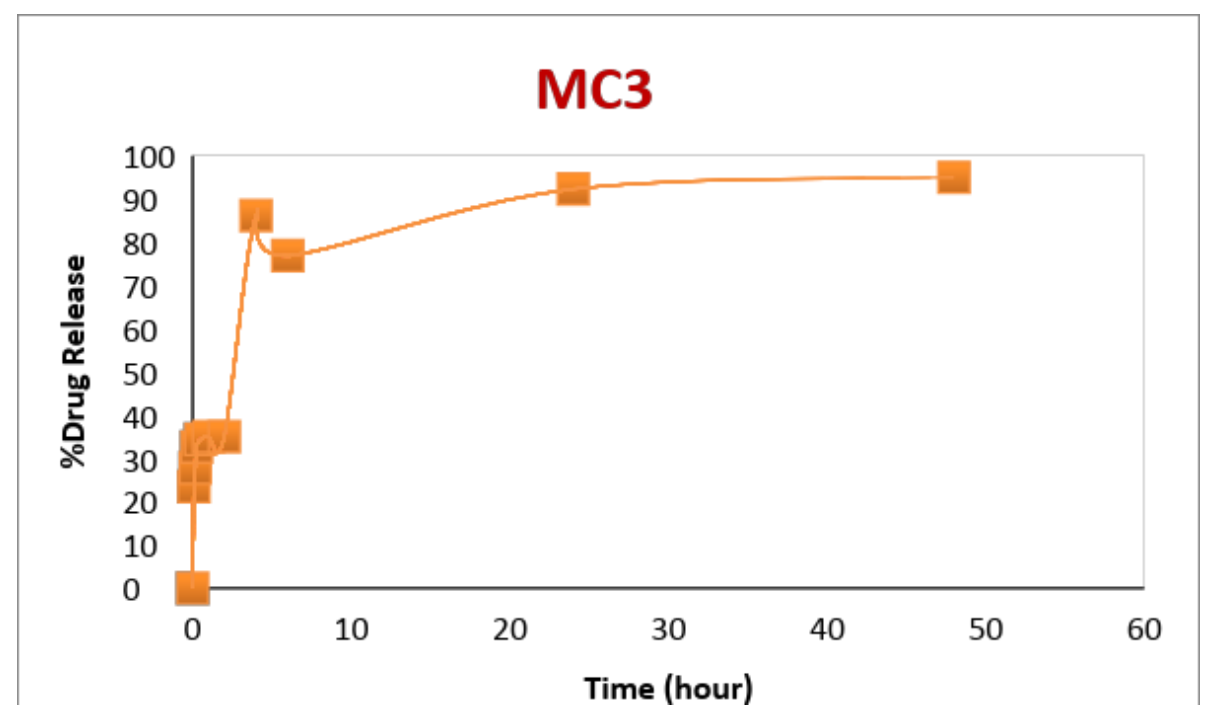

Figure 4. Drug release \% of metoprolol tartarate

\section{DISCUSSION}

$\begin{array}{lrr}\begin{array}{l}\text { Chitosan, a } \\ \text { biopolyaminosaccharide, }\end{array} & \text { natural } & \text { linear } \\ \text { gas } & \text { good }\end{array}$ biocompatibility, nontoxicity, biodegradability, good mucoadhesivity and absorption-enhancing effects. Whereas it has one primary amino group and two free hydroxyl groups, it carries a positive charge and reacts with many negatively charged structures such as the cell membrane, mucus lining and also anionic polymers ${ }^{17}$. On the other hand, tripolyphosphate, a polyanion, can interact with the cationic chitosan by electrostatic forces. Considering the complexation between oppositely charged species, chitosan undergoes ionic gelation and precipitates to form spherical particles ${ }^{18}$. We investigated the optimum ratio between chitosan and tripolyphosphate. Low amount of TPP prevented micro-sized particles independently of chitosan amount. As seen in Table 3, the yield of microparticles decreased when the TPP amount increased in each chitosan amount. It can be linked to the formation of nano-sized particles instead of microparticles. Increased TPP reacted more chitosan leading to smaller microparticles. Particle size is one of the indicators of product quality and performance. It influences several parameters from appearance to dissolution rate and effectiveness ${ }^{19}$. The particle sizes ranged from $52 \mu \mathrm{m}$ to $106 \mu \mathrm{m}$ and the yield was able to be augmented up to $88 \%$. The swelling degree in formulations reached to $41 \%$, following $37 \%$ and $33 \%$ in acidic medium. However, it remained restricted below 2 \%in basic medium. It was clearly implied that MT was easily released in acidic medium under the influence of swelling release mechanism, hence dose dumping of MT in stomach could show up before the drug reached to absorption site. It is out of favour in controlled release systems. On the other hand, minimum swelling behavior mechanism in basic medium was obtained and it indicated the possibility of controlled release in small intestine where the drugs mainly absorbed. Taking into account all of these experiments, the F14 coded formulation was selected as optimum formulation. It had 1.5:0.375 chitosan:TPP ratio with $81 \%$ of yield and $75.373 \pm 7.384 \mu \mathrm{m}$ particle size. To determine the amount of MT, the quantitation method using spectrophotometer was developed. The maximum absorbance was obtained at $274 \mathrm{~nm}$ for MT. These results were parallel to previous determination studies performed by the same equipment ${ }^{20}$. The method was validated for MT in $0.1 \mathrm{~N} \mathrm{HCl} \mathrm{pH} 1.2$ and PBS pH 6.8 in terms of linearity, selectivity, recovery, precision and 
accuracy. Entrapment efficiency and drug loading studies underlined that the more drug used in formulations, the more entrapment efficiency obtained. MC5 tended to aggregate and it was found non-suitable for further studies. Since MC3 and MC4 found similar for entrapment efficiency and drug loading, incubation step was disregarded. Cytotoxicity tests emphasized that chitosan microparticles were non-toxic. The drug release reached to approximately $40 \%$ in the first two hours, acidic medium. After that, basic medium led to the deceleration of drug release and the drug release reached to $100 \%$ in 48 hours. As a consequence, this developed formulation could have promising potential when prevention of drug release in stomach achieved, for instance using enteric coating.

\section{Acknowledgement}

This study is financially supported by the Scientific and Technological Research Council of Turkey (TÜBITTAK 2209-A University Students Research Projects Support Program).

\section{REFERENCES}

1. Makridakis S, DiNicolantonio JJ. Hypertension: empirical evidence and implications in 2014. Open Heart. 2014;1:e000048. doi:10.1136/openhrt-2014-000048.

2. Doğan AS, Yenicesu C, Sucaklı MH, Özdemir Ö, Demirel Y. Hipertansif hastaların ailelerinde Apo E gen polimorfizmleri ve kan lipit profillerinin değerlendirilmesi. Cumhuriyet Medical Journal. 2014; 36: 459-465.

3. Pinto1 IC, Martins D. Prevalence and risk factors of arterial hypertension: A literature review. J Cardiovasc Med Ther. 2017; 1(2): 1-7.

4. Laurent S. Antihypertensive drugs. Pharmacological Research .2017; 127: 116-125.

5. Wiysonge CS, Bradley HA, Volmink J, Mayosi BM, Opie LH. Beta-blockers for hypertension. Cochrane Database of Systematic Reviews. 2017; 1:1-93.

6. Özdemir L, Sümer H. The effect of educational intervention on blood pressure levels among hypertensive female patients aged over 30 and living in Sivas. Cumhuriyet Med J. 2009; 31: 3140.

7. Kushal M, Monali M, Durgavati M et al. Oral controlled release drug delivery system: an overview. International research journal of pharmacy. 2013; 4(3):70-76.
8. Moorthi C, Manavalan R, Kathiresan K. Nanotherapeutics to Overcome Conventional Cancer Chemotherapy Limitations. J Pharm Pharmaceut Sci. 2011; 14(1): 67-77.

9. Perrie Y, Rades T (eds). Controlling Drug Delivery. in Pharmaceutics - Drug Delivery and Targeting, 2nd edn. New Zealand: Pharmaceutical Press, 2012.

10. Prisant LM, Elliott WJ. Drug Delivery Systems for Treatment of Systemic Hypertension. Clin Pharmacokinet. 2003; 42 (11): 931-940.

11. Mothilal M, Nagalakshmi M, Swati PS et al. Optimisation and characetrisation of chitosan microspheres of aceclofenac. International Journal of Pharma Sciences and Research. 2012; 3(2): 305-315.

12. Stoica R, Somoghi R, Ion RM. Preparation of chitosan - tripolyphosphate nanoparticles for the encapsulation of polyphenols extracted from rose hips. Digest Journal of Nanomaterials and Biostructures. 2013; 8(3): 955-963.

13. Sun Q, Han D, Lei $H$ et al. Preparation and Characterization of Chitosan Microsphere Loading Bovine Serum Albumin. Journal of Wuhan University of Technology-Mater Sci Ed. 2012; 27(3): 459-464.

14. Patel KS, Patel MB. Preparation and evaluation of chitosan microspheres containing nicorandil. Int J Pharm Investig. 2014; 4(1): 3237.

15. Buiza OD, Dima C, Dima S. Preparation and characterization of chitosan microspheres for vancomycin delivey. Farmacia. 2015; 63(6): 897902.

16. Kumar K, Dhawan N, Sharma H et al. Bilayer mucoadhesive microparticles for the delivery of metoprolol succinate: Formulation and evaluation. Artificial Cells, Nanomedicine, and Biotechnology. 2014; 1-6.

17. Kunjachan $\mathrm{S}$, Jose $\mathrm{S}$, Lammers $\mathrm{T}$. Understanding the mechanism of ionic gelation for synthesis of chitosan nanoparticles using qualitative techniques. Asian Journal of Pharmaceutics. 2010; 148-153.

18. Mitra A, Dey B. Chitosan Microspheres in Novel Drug Delivery Systems. Indian J Pharm Sci. 2011; 73(4): 355-366.

19. Demir GM, Değim IT. Preparation of Chitosan Nanoparticles by Nano Spray Drying Technology. FABAD J. Pharm. Sci. 2013; 38(3): 127-133. 
20. Khan S, Gajbhiye C, Singhavi DJ, Yeole P. In situ Gel of Metoprolol Tartrate: Physicochemical Characterization, In vitro Diffusion and Histological Studies. Indian J Pharm Sci. 2012; 74(6): 564-570. 